\title{
Effects of insulin-like growth factor on nitrogen balance during hypoxic exposure
}

\author{
Y. lioka, K. Tatsumi, K. Sugito, T. Moriya, T. Kuriyama
}

Effects of insulin-like growth factor on nitrogen balance during hypoxic exposure. Y. Iioka, K. Tatsumi, K. Sugito, T. Moriya, T. Kuriyama. (C) ERS Journals Ltd 2002. ABSTRACT: Acute exacerbations of chronic obstructive pulmonary disease (COPD) accompanied with hypoxaemia may induce net protein catabolism and hypoxaemia could be an important trigger of a systemic catabolic response. The aim of this study was to examine the anabolic effects of recombinant human insulin-like growth factor-I (IGF-I) in rats exposed to hypoxia. Although acute hypoxia is usually accompanied with a decrease in dietary intake, the usual nitrogen intake was maintained in this study.

Sprague-Dawley rats were maintained by continuous infusion of solution for total parenteral nutrition for 6 days. The animals were then randomly assigned to a normoxic (N) or a hypoxic $(\mathrm{H})$ group. During the last 3 days of the experiment $\mathrm{N}$ and $\mathrm{H}$ rats were randomised to receive either IGF-I or vehicle.

Exposure to hypoxia caused a decrease in body-weight gain accompanied by a negative nitrogen balance, which was mainly due to increased urinary nitrogen excretion. No effect of recombinant human IGF-I treatment on body weight was observed during exposure to hypoxia, although nitrogen balance normalised.

The co-infusion of recombinant human insulin-like growth factor-1 and total parenteral nutrition has a significant net anabolic effect, as demonstrated by nitrogen retention and reduction in urine protein excretion observed in rats. Insulin-like growth factor-1 may help to ameliorate the protein catabolism observed under hypoxic conditions.

Eur Respir J 2002; 20: 293-299.
Dept of Respirology, Graduate School of Medicine, Chiba University, Chiba, Japan.

Correspondence: K. Tatsumi, Dept of Respirology (B2), Graduate School of Medicine, Chiba University, 1-8-1 Inohana, Chuou-ku, Chiba 260-8670, Japan.

Fax: 81432262176

E-mail: tatsumi@med.m.chiba-u.ac.jp

Keywords: Catabolism, hypoxia, insulin growth factor-1, nitrogen balance, total parenteral nutrition

Received: April 52001

Accepted after revision: January 12 2002

This study was supported by research grants to the Respiratory Failure Research Group from the Ministry of Health, Labour and Welfare, Japan.
A substantial proportion of patients with moderateto-severe chronic obstructive pulmonary disease (COPD) exhibit an elevated resting metabolic rate [1]. A subset of these patients display increased levels of acute-phase proteins and soluble tumour necrosis factor (TNF)-receptors in peripheral blood [2], and it is possible that the TNF system and weight loss are related [3]. These patients are further characterised by a depletion of fat-free mass, independent of the body mass index [2]. Therefore, tissue depletion in patients with COPD may be related in part to a systemic catabolic response induced by inflammation, which cannot be completely reversed by nutritional support alone. Cellular energy metabolism is altered in muscle biopsies of patients with clinically stable COPD at rest, independent of their muscle mass. Chronic or intermittent hypoxaemia could be an important trigger of these metabolic alterations [4].

Body-weight loss and depletion of fat-free mass is a serious problem in patients with COPD, negatively affecting their exercise capacity and survival rates [4, 5]. Protein metabolism is likely to be altered in COPD patients, as suggested by the results of an investigation of the amino-acid levels in skeletal muscles [6]. An increased whole-body protein turnover, which consisted of enhanced levels of both protein synthesis and breakdown, was observed in clinically stable patients

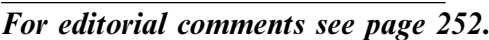

with severe COPD who had a stable body weight and less free-fat mass than control subjects [7]. However, it remains unclear whether acute exacerbations of COPD or progressive weight loss, which usually occurs in COPD and is accompanied with hypoxaemia, induces net protein catabolism in these patients.

Total parenteral nutrition (TPN), although it does not totally prevent body protein loss, is commonly used to provide nutritional support during catabolic illness [8]. Thus, the possibility of administering an anabolic agent, such as growth hormone $(\mathrm{GH})[9]$ or insulin-like growth factor I (IGF-I) [10], during TPN is under investigation. The anabolic effects of recombinant human IGF-I (rhIGF-I) have been demonstrated in animals in which catabolism has been induced by diabetes [11] or inadequate nutrition [12]. However, the anabolic effects of IGF-I during TPN in catabolic states, such as hypoxaemic conditions need to be assessed. The objective of the present study was to examine the anabolic effects of rhIGF-I co-infused with TPN in rats under hypoxic conditions.

\section{Methods}

The animal facilities and protocols were approved by the Chiba University School of Medicine Animal Care and Use Committee. 


\section{Animals and surgery}

Male, specific pathogen-free, Sprague-Dawley rats (200-220 g; Charles River, Yokohama, Japan) were housed in individual stainless steel cages under a 12-h light-dark cycle and allowed free access to water. Animals were allowed to adapt to the animal facilities for 7 days before the experiment. After anaesthesia $\left(50 \mathrm{mg} \cdot \mathrm{kg}^{-1}\right.$ ketamine and $5 \mathrm{mg} \cdot \mathrm{kg}^{-1}$ xylazine administered by intramuscular injection), a catheter was surgically placed in the superior vena cava via the external jugular vein [13]. Surgery was followed by a 3 -day recovery period during which the animals could eat standard rat chow ad libitum. During the recovery period, an electrolyte solution $\left(60 \mathrm{~mL} \cdot\right.$ day $\left.^{-1}\right)$ was administered in addition to the rat chow.

\section{Experimental design}

After the recovery period, the animals $(n=24)$ were maintained exclusively by continuous infusion of the TPN solution, using a 22-gauge swivel-infusion assembly (BRC, Nagoya, Japan), for 6 days. Throughout the infusion period the animals were allowed to move freely within the cage.

Animals were randomly assigned to either a normoxic $(\mathrm{N})(\mathrm{n}=12)$ or a hypoxic $(\mathrm{H})(\mathrm{n}=12)$ group. After 3-day baseline measurements during normoxia, $\mathrm{H}$ rats were placed for 3 days in a normobaric hypoxic environmental chamber where the fractional inspired oxygen $\left(\mathrm{O}_{2}\right)$ concentration was maintained at $10 \%$, with excess humidity and carbon dioxide $\left(\mathrm{CO}_{2}\right)$ was removed by means of soda lime and silica gel. The volume of the chamber was $0.3645 \mathrm{~m}^{3} \quad(90 \times 90 \times$ $45 \mathrm{~cm})$. The hypoxic environment was maintained by a flow of hypoxic air at $6 \mathrm{~L} \cdot \mathrm{min}^{-1}$. This hypoxic air was produced by remodelling adsorption-type oxygen concentrators to utilise exhaust air (Teijin, Tokyo, Japan). Gas was sampled periodically and $\mathrm{O}_{2}$ and $\mathrm{CO}_{2}$ were analysed in a gas analyser (NEC-San-Ei Instruments, 1H26, Tokyo). The fractional inspired $\mathrm{CO}_{2}$ concentration was shown to be $<0.04 \%$ throughout the experiment. The temperature in the chamber varied with room temperature from $20-25^{\circ} \mathrm{C}$. N rats were kept in air in the same room as the $\mathrm{H}$ animals and were exposed to the same light/dark cycle. The chamber was opened once a day for $<30 \mathrm{~min}$ to measure body weight and collect urine samples.

During the last 3 days, $\mathrm{N}$ and $\mathrm{H}$ rats were randomised to continuously receive either $4 \mathrm{mg} \cdot \mathrm{kg}^{-1} \cdot \mathrm{day}^{-1}$ of IGF-I $(n=6)(\mathrm{IGF}-\mathrm{I}(+))$ or isotonic saline $(n=6)$ (control group (IGF-I(-)). Each of the four treatment groups initially comprised of six animals, but one animal was lost by the end of the experiment because of catheter problems. The final sample size was as follows: N IGF-I(-) $(n=5)$, N IGF-I $(+)(n=6)$, H IGF$\mathrm{I}(-)(\mathrm{n}=6), \mathrm{H}$ IGF-I(+) $(\mathrm{n}=6)$.

At the end of this study, after the femoral vein was cannulated to collect blood to measure serum total protein and albumin, the rats were killed with an overdose of pentobarbital sodium. The gastrointestinal tract was removed and flushed with cold saline to remove gut contents. Liver, kidneys, spleen, thymus, lungs, stomach, small intestine (from pylorus to cecum), cecum, colon (between cecum and rectum) and gastrocnemius muscles were dissected and weighed. Then the carcasses were stored at $-5^{\circ} \mathrm{C}$ until measurements of protein concentration in each organ could be taken.

\section{Composition of total parenteral nutrition}

TPN solution was prepared aseptically using commercial preparations of $12 \%$ amino acids (Proteamin12; Tanabe Pharmaceutical Co., Ltd, Tokyo, Japan), glucose, 20\% lipid emulsion (Intralipid, Ootsuka Pharmaceutical Co., Ltd, Tokyo, Japan), vitamins, trace elements and electrolytes [13]. Animals received $60 \pm 2 \mathrm{~mL}$ TPN$\cdot \mathrm{day}^{-1}$, which provided $400 \mathrm{mg}$ nitrogen $\cdot$ day $^{-1}$ and $62 \mathrm{Kcal} \cdot \mathrm{day}^{-1}$.

\section{Body protein concentration}

The freeze-dried carcasses were homogenised and aliquots of dried rat homogenate were assayed for nitrogen concentrations in triplicate. The concentration of nitrogen in the lungs, liver, kidneys, stomach, intestine, colon and gastrocnemius muscles was determined by micro-Kjeldahl analysis of $0.20 \mathrm{~g}$ dried rat homogenate, and the protein concentration was calculated by multiplying the concentration of nitrogen in the carcass by 6.25 [14].

\section{Analytical measurements}

Body weights were recorded daily and urine was collected and stored in $0.01 \%$ boric acid at $4{ }^{\circ} \mathrm{C}$ before determination of nitrogen concentration. The nitrogen content of urine samples was determined by a modified micro-Kjedahl procedure [15]. Nitrogen balance was determined by subtracting total urinary nitrogen from total nitrogen intake, which was calculated from the volume of TPN solution given. As faecal losses are minimal in animals maintained with TPN, faecal nitrogen was not determined.

\section{Statistical analysis}

Values are expressed as mean \pm SE. Statistical analysis was performed by analysis of variance (ANOVA) and subsequent multiple comparisons by Scheffe's test. To examine the effects of exposure to hypoxia, $\mathrm{N}$ IGF-I(-) and H IGF-I(-) were compared. To examine the effects of IGF-I treatment, IGF-I(-) and IGF-I(+) subgroups within the $\mathrm{N}$ and $\mathrm{H}$ groups were compared. Significance was set at $\mathrm{p}<0.05$.

\section{Results}

In IGF-I(-) animals, serum total protein and albumin were lower in $\mathrm{H}$ rats than in $\mathrm{N}$ rats. In contrast, the levels of total cholesterol and triglycerides did not differ between the two groups (table 1). 
Table 1. - Serum levels of protein and lipids

\begin{tabular}{lrcrc}
\hline Treatment group & Normoxia/IGF-I(-) & Normoxia/IGF-I(+) & Hypoxia/IGF-I(-) & Hypoxia/IGF-I(+) \\
\hline Total protein $\mathrm{g} \cdot \mathrm{dL}^{-1}$ & $5.9 \pm 0.1$ & $6.0 \pm 0.1$ & $5.5 \pm 0.1^{*}$ & $5.7 \pm 0.1$ \\
Albumin $\mathrm{g} \cdot \mathrm{dL}^{-1}$ & $3.5 \pm 0.1$ & $3.7 \pm 0.1$ & $3.2 \pm 0.1^{*}$ & $3.3 \pm 0.1$ \\
Total cholesterol $\mathrm{mg}^{-} \mathrm{dL}^{-1}$ & $77.8 \pm 7.0$ & $76.3 \pm 6.0$ & $75.0 \pm 6.9$ & $66.1 \pm 2.2$ \\
Triglyceride $\mathrm{mg} \cdot \mathrm{dL}^{-1}$ & $18.2 \pm 4.0$ & $25.0 \pm 5.0$ & $19.5 \pm 3.1$ & $19.0 \pm 1.9$ \\
\hline
\end{tabular}

Data are presented as mean \pm SE. IGF-I(-): rats not treated with insulin-like growth factor-I(IGF-I); IGF-I(+) rats treated with IGF-I. *: $\mathrm{p}<0.05$ versus normoxia/IGF-I(-).

Because the baseline body weight was similar in all four groups (mean values 209-222 g), the body-weight gain was compared (fig. 1). The body weight was decreased on day 1 after exposure to hypoxia in IGFI(-) rats. Exposure to hypoxia had a significant impact

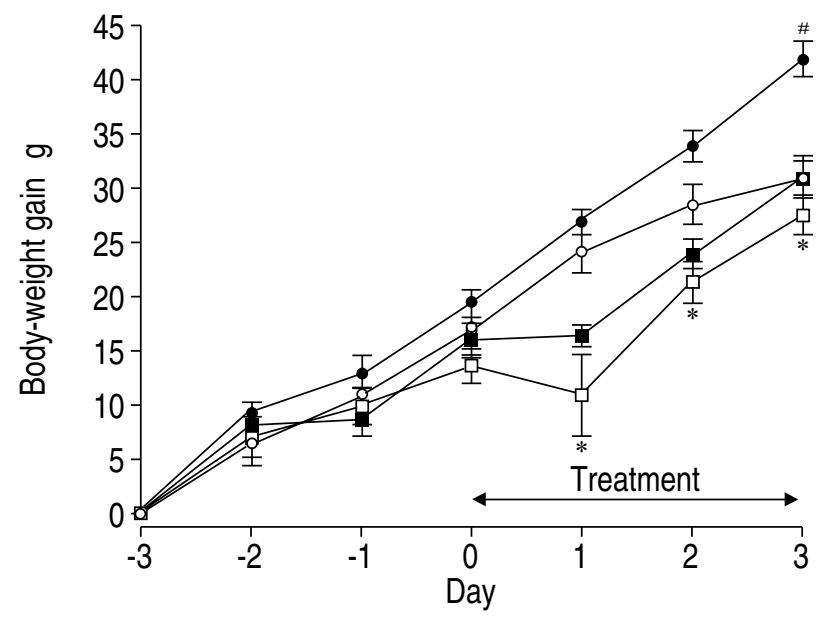

Fig. 1.-Accumulative body-weight gain during continuous infusion of total parenteral nutrition solution in normoxic $(\mathrm{N})$ or hypoxic $(\mathrm{H})$ and insulin-like growth factor-I-treated $(\mathrm{IGF}-\mathrm{I}(+))$ or untreated (IGF-I(-)) rats. $\bigcirc: \mathrm{N}$ rat IGF-I(-); $0: \mathrm{N}$ rat IGF-I(+); $\square$ : H rat IGF-I(-); $\mathbf{a}$ : H rat $\operatorname{IGF}-\mathrm{I}(+) . *$ : $\mathrm{p}<0.05$ compared with $\mathrm{N}$ rat IGF-I(-); ${ }^{\#}: \mathrm{p}<0.05$ compared with $\mathrm{N}$ rat IGF-I (-).

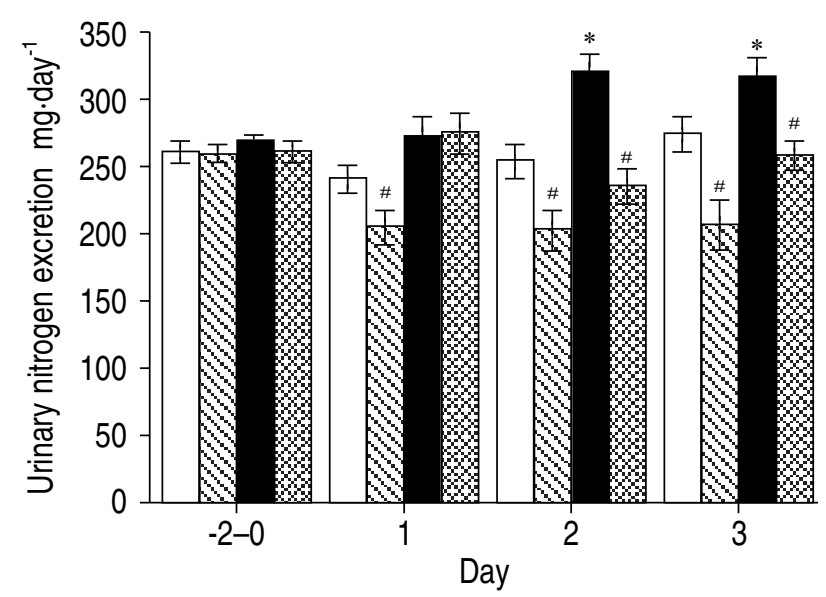

Fig. 2.-Urinary nitrogen excretion during continuous infusion of total parenteral nutrition solution in normoxic $(\mathrm{N})$ or hypoxic $(\mathrm{H})$ and insulin-like growth factor-1-treated $(\mathrm{IGF}-\mathrm{I}(+))$ or untreated (IGF-I(-)) rats. Pooled data are presented for pretreatment period

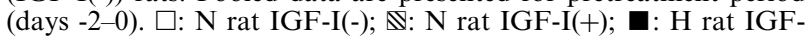
$\mathrm{I}(-)$; $\mathbf{0}$; rat $\mathrm{IGF}-\mathrm{I}(+)$. *: $\mathrm{p}<0.05$ compared with $\mathrm{N}$ rats IGF-I $(-) ;{ }^{\#}: \mathrm{p}<0.05$ compared with IGF-I(-) $\mathrm{N}$ or $\mathrm{H}$ counterparts. on body weight, namely, among IGF-I(-) animals body weight was higher in $\mathrm{N}$ rats than in $\mathrm{H}$ rats throughout days $1-3(\mathrm{p}<0.05)$. The effect of IGF-I $(+)$ treatment on body-weight gain was observed only on day 3 in N rats, compared with IGF-I $(-)$ rats $(\mathrm{p}<0.05)$, whereas, IGF-I $(+)$ treatment had no effect on the body weight of $\mathrm{H}$ rats.

Nitrogen excretion and retention data are summarised in figures 2 and 3. The pretreatment values were averaged in each group for 3 days (day -2-0). During the 3 days before IGF-I or vehicle treatment, nitrogen excretion and retention did not differ significantly among the groups. Thus, pooled data are presented for the pretreatment period. Nitrogen intake did not differ significantly among groups throughout the 6 days on TPN.

Nitrogen excretion increased $\sim 20 \%$ in IGF-I(-) $\mathrm{H}$ rats, while it did not increase in IGF-I(-) $\mathrm{N}$ rats. IGF-I attenuated the increase in nitrogen excretion induced by exposure to hypoxia on days 2 and 3 , so that nitrogen excretion was similar to that observed at baseline. Similarly IGF-I attenuated nitrogen excretion throughout the treatment period (day 1-3) in $\mathrm{N}$ rats.

Nitrogen balance was not affected in IGF-I(-) N rats, because nitrogen intake was constant and nitrogen excretion remained nearly unchanged. In contrast, IGF-I treatment produced a positive nitrogen balance in $\mathrm{N}$ rats. IGF-I(-) $\mathrm{H}$ rats showed a negative nitrogen balance, while IGF-I treatment prevented it. The

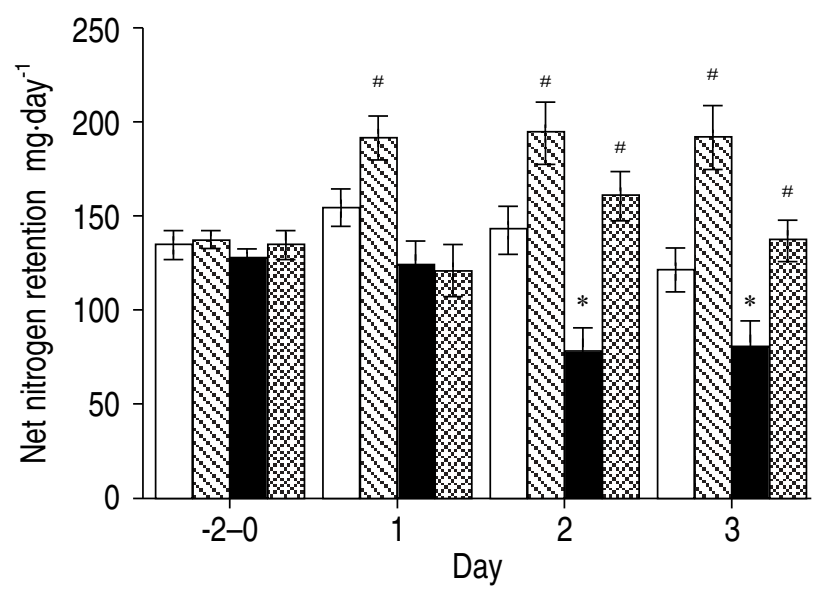

Fig. 3.-Urinary nitrogen retention during continuous infusion of total parenteral nutrition solution in normoxic $(\mathrm{N})$ or hypoxic $(\mathrm{H})$ and insulin-like growth factor-1-treated $(\mathrm{IGF}-\mathrm{I}(+))$ or untreated (IGF-I(-)) rats. Pooled data are presented for the pretreatment period (days $-2-0)$. $\square: \mathrm{N}$ rat IGF-I( - ; $\mathbb{\mathbb { N }}: \mathrm{N}$ rat $\operatorname{IGF}-\mathrm{I}(+) ; \mathbf{\square}: \mathrm{H}$ rat IGF-I(-); $\mathrm{H}$ rat IGF-I(+). *: $\mathrm{p}<0.05$ compared with $\mathrm{N}$ rats IGF-I(-); ${ }^{\#}: \mathrm{p}<0.05$ compared with IGF-I(-) N or H counterparts. 


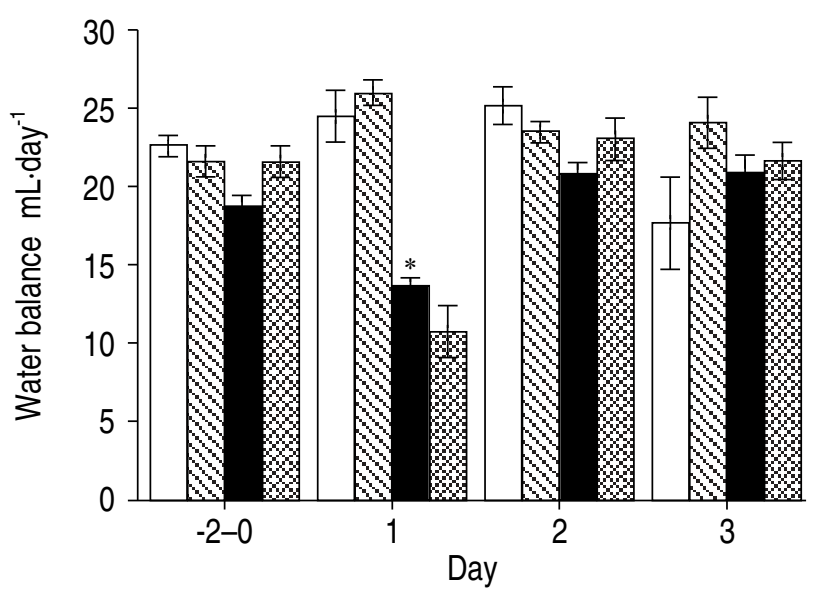

Fig. 4.-Water balance during continuous infusion of total parenteral nutrition solution in normoxic $(\mathrm{N})$ or hypoxic $(\mathrm{H})$ and insulin-like growth factor-1-treated $(\mathrm{IGF}-\mathrm{I}(+))$ or untreated (IGF$\mathrm{I}(-))$ rats. Pooled data are presented for pretreatment period (days $-2-0)$. $\square: \mathrm{N}$ rat IGF-I(-); $\mathbb{\mathbb { N }}: \mathrm{N}$ rat IGF-I(+); $\mathbf{\square}: \mathrm{H}$ rat IGF-I(-);

; H rat IGF-I(+). *: $\mathrm{p}<0.05$ compared with $\mathrm{N}$ rats IGF-I(-).

degree of positive water balance decreased only on the first day of exposure to hypoxia. In both IGF-I(-) and $\mathrm{IGF}-\mathrm{I}(+) \mathrm{H}$ rats, the increase in urine volume resulted in a decrease in the water balance (fig. 4).

The relative weight $\left(\mathrm{g} \cdot \mathrm{kg}\right.$ body weight $\left.{ }^{-1}\right)$ of each organ is shown in table 2 . The effect of hypoxia was observed in the lungs and thymus. Lungs weight was higher and that of the thymus was lower in IGF-I(-) $\mathrm{H}$ rats compared with IGF-I(-) $\mathrm{N}$ rats. The influence of IGF-I treatment was observed in the weight of kidneys, stomach, intestine and colon in both $\mathrm{N}$ and $\mathrm{H}$ rats. The relative organ weights of rats treated with IGF-I were higher. The protein content in the intestine tended to increase in $\mathrm{N}$ rats $(\mathrm{p}=0.07)$ and was significantly higher in $\mathrm{H}$ rats. No effect of IGF-I was observed in other organs apart from the intestine (table 3).

\section{Discussion}

The in vivo anabolic effects of rhIGF-I have been extensively examined in both humans and animals $[11,12,14,16]$. However, the effects of IGF-I co-infused with TPN during hypoxia have not been investigated previously $[14,17]$. The results of this study indicate that IGF-I is anabolic in $\mathrm{N}$ rats given TPN, as shown by a greater weight gain and nitrogen retention compared with $\mathrm{N}$ rats maintained with TPN but not given IGF-I. Furthermore, the present results confirm previous findings by demonstrating that IGFI has a net anabolic effect when co-infused with TPN in animals made catabolic by exposure to hypoxia. This study also demonstrates that exposure to hypoxia caused a decrease in the degree of body-weight gain

Table 2. - Organ weights body weight ${ }^{-1}$

\begin{tabular}{|c|c|c|c|c|}
\hline Treatment group & Normoxia/IGF-I(-) & Normoxia/IGF-I(+) & Hypoxia/IGF-I(-) & Hypoxia/IGF-I(+) \\
\hline Final body weight $g$ & $238 \pm 5$ & $254 \pm 7^{\#}$ & $242 \pm 2$ & $253 \pm 4$ \\
\hline Heart $\mathrm{g} \cdot \mathrm{kg}^{-1}$ & $3.9 \pm 0.1$ & $3.9 \pm 0.1$ & $4.0 \pm 0.1$ & $4.2 \pm 0.1$ \\
\hline Lung $\mathrm{g} \cdot \mathrm{kg}^{-1}$ & $4.6 \pm 0.2$ & $4.8 \pm 0.1$ & $5.3 \pm 0.1^{*}$ & $5.7 \pm 0.2$ \\
\hline Thymus $\mathrm{g} \cdot \mathrm{kg}^{-1}$ & $2.8 \pm 0.4$ & $3.2 \pm 0.2$ & $2.0 \pm 0.1 *$ & $2.3 \pm 0.1$ \\
\hline Liver $\mathrm{g} \cdot \mathrm{kg}^{-1}$ & $39.4 \pm 1.0$ & $41.2 \pm 0.6$ & $38.9 \pm 1.2$ & $40.3 \pm 1.0$ \\
\hline Spleen $\mathrm{g} \cdot \mathrm{kg}^{-1}$ & $40.0 \pm 1.0$ & $41.2 \pm 0.6$ & $38.9 \pm 1.2$ & $40.3 \pm 1.0$ \\
\hline Kidney $\mathrm{g} \cdot \mathrm{kg}^{-1}$ & $8.5 \pm 0.2$ & $9.2 \pm 0.2^{\#}$ & $8.2 \pm 0.2$ & $9.1 \pm 0.2^{\#}$ \\
\hline Stomach $\mathrm{g} \cdot \mathrm{kg}^{-1}$ & $4.0 \pm 0.2$ & $4.5 \pm 0.1^{\#}$ & $4.0 \pm 0.1$ & $4.6 \pm 0.1^{\#}$ \\
\hline Intestine $\mathrm{g} \cdot \mathrm{kg}^{-1}$ & $16.9 \pm 0.4$ & $22.2 \pm 0.9^{\#}$ & $16.8 \pm 0.7$ & $21.5 \pm 0.4^{\#}$ \\
\hline Cecum $\mathrm{g} \cdot \mathrm{kg}^{-\mathrm{\rho}}$ & $2.9 \pm 0.2$ & $3.1 \pm 0.2$ & $2.7 \pm 0.1$ & $3.0 \pm 0.1$ \\
\hline Colon $\mathrm{g} \cdot \mathrm{kg}^{-1}$ & $3.6 \pm 0.1$ & $4.2 \pm 0.2^{\#}$ & $3.8 \pm 0.1$ & $4.1 \pm 0.1^{\#}$ \\
\hline Gastrocnemius muscles $\mathrm{g} \cdot \mathrm{kg}^{-1}$ & $6.6 \pm 0.1$ & $6.5 \pm 0.2$ & $6.7 \pm 0.1$ & $6.6 \pm 0.2$ \\
\hline
\end{tabular}

Data are presented as mean \pm SE. IGF-I(-): rats not treated with insulin-like growth factor-I(IGF-I); IGF-I(+): rats treated with IGF-I. *: $\mathrm{p}<0.05$ versus normoxia/IGF-I(-); ${ }^{\#}$ : $\mathrm{p}<0.05$ versus IGF-I(-) groups.

Table 3. - Protein content in each organ

\begin{tabular}{|c|c|c|c|c|}
\hline Treatment group & Normoxia/IGF-I(-) & Normoxia/IGF-I(+) & Hypoxia/IGF-I(-) & Hypoxia/IGF-I(+) \\
\hline Lung $\mathrm{g} \cdot \mathrm{kg}^{-1}$ & $0.46 \pm 0.05$ & $0.40 \pm 0.02$ & $0.45 \pm 0.04$ & $0.45 \pm 0.04$ \\
\hline Liver $\mathrm{g} \cdot \mathrm{kg}^{-1}$ & $3.81 \pm 0.34$ & $4.06 \pm 0.21$ & $4.00 \pm 0.21$ & $4.33 \pm 0.31$ \\
\hline Kidney $\mathrm{g} \cdot \mathrm{kg}^{-1}$ & $0.58 \pm 0.03$ & $0.63 \pm 0.05$ & $0.61 \pm 0.02$ & $0.68 \pm 0.03$ \\
\hline Stomach $\mathrm{g} \cdot \mathrm{kg}^{-1}$ & $0.26 \pm 0.01$ & $0.28 \pm 0.04$ & $0.21 \pm 0.02$ & $0.26 \pm 0.02$ \\
\hline Intestine $\mathrm{g} \cdot \mathrm{kg}^{-1}$ & $0.73 \pm 0.04$ & $0.91 \pm 0.07$ & $0.62 \pm 0.06$ & $0.94 \pm 0.04^{\#}$ \\
\hline Colon $\mathrm{g} \cdot \mathrm{kg}^{-1}$ & $0.22 \pm 0.01$ & $0.21 \pm 0.02$ & $0.21 \pm 0.01$ & $0.21 \pm 0.01$ \\
\hline Gastrocnemius muscles $\mathrm{g} \cdot \mathrm{kg}^{-1}$ & $0.53 \pm 0.05$ & $0.48 \pm 0.05$ & $0.53 \pm 0.03$ & $0.49 \pm 0.03$ \\
\hline
\end{tabular}

Data are presented as mean \pm SE. IGF-I(-): rats not treated with insulin-like growth factor-I(IGF-I); IGF-I(+): rats treated with IGF-I. \#: $\mathrm{p}<0.05$ versus IGF-I(-) groups. 
accompanied by a negative nitrogen balance, which was due mainly to an increased urinary nitrogen excretion. No effect of IGF-I treatment on body weight was observed during the 3 days of exposure to hypoxia, although the nitrogen balance normalised.

The causes of weight loss related to hypoxia remain undefined. Anorexia with hypophagia is known to be almost always associated with hypoxia, which is attributed to one of the main factors of weight loss $[18,19]$. However, in this study, total calorific and nitrogen intake was continuously maintained by TPN. Therefore, hypoxia per se may have exerted a major influence on body weight.

The impaired body-weight gain during the first 24-h exposure to hypoxia may have been due partly to the relatively negative water balance [18]. The amount of water intake was constant during the experiment in this study, thus the diuretic effect related to exposure to hypoxia may have influenced the water balance. Hormones and cytokines are known to be modified under acute stress [20] and, therefore, may be affected by hypoxia. For example, lipopolysaccharide-induced release of TNF and interleukin (IL)- $\beta$ has been shown to be enhanced after exposure to hypoxia [21]. Any change in hormonal homeostasis related to diuretics may have influenced the water balance in the present study, although the exact mechanisms have not been defined.

The direct effect of hypoxia on the metabolic balance between protein synthesis and breakdown may have influenced the impaired body-weight gain. Hypoxaemic patients with emphysema have shown muscle wasting due to a depressed protein synthesis, accompanied by an overall fall in whole-body protein turnover [22]. Therefore, hypoxia may cause a decrease in proteosynthesis rather than an increase in proteolysis. In addition, it has been shown that fasting hypoxic rats show lower plasma amino-acid concentrations compared with normoxic rats, suggesting that proteosynthesis is depressed during hypoxaemia [23].

Circulating IGF-I may play an integrative role in the control of protein metabolism whilst fasting [17] and it may serve as an index of nutritional status [24]. Protein malnutrition not only decreases IGF-I production, but also enhances its serum clearance and degradation [24]. Thus, IGF-I and nutrition are closely related.

The effects of IGF-I on protein metabolism are likely to vary under different nutritional conditions and catabolic status. The anabolic effects of IGF-I during TPN are most likely mediated by changes in both protein catabolism and synthesis [14, 17]. Body protein analysis during the 3 days of treatment with IGF-I showed a significant increase only in the intestine of $\mathrm{H}$ rats. Although the effect of IGF-I on body-weight gain was not observed until day 3 in $\mathrm{N}$ rats, a positive nitrogen balance was already observed on day 1 . In $\mathrm{H}$ rats the effect of IGF-I on nitrogen balance appeared on day 2 , but it did not influence body-weight gain. The results of this study demonstrated that the effect of IGF-I on nitrogen balance could be recognised within 1 day under normoxic conditions, while it required 2 days under hypoxic conditions. In contrast, a positive nitrogen balance after 1 week of treatment with IGF-I was reported in a previous human study [25].

IGF-I infusion has been shown to decrease the rate of net protein catabolism and increase the fractional synthetic rate of protein in cardiac and diaphragmatic muscle in fasted and parenterally fed lambs. The administration of IGF-I to catabolic animals not only decreases endogenous protein loss, but when administered together with nutritional support, enhances the utilisation of the substrates [17]. Whether the rate of protein synthesis was augmented by IGF-I treatment was undefined in the present study. However, the loss of endogenous protein decreased during the administration of IGF-I, as shown by the decrements in urinary nitrogen excretion.

Changes in the circulating levels of IGF-binding proteins (IGFBPs) may contribute to the effects of coinfusion of IGF-I with TPN on nitrogen balance, because IGFBPs influence the clearance and/or tissue distribution of IGF-I during TPN [26, 27]. However, these were not measured in this study. Among them, IGFBP-3 is the predominant carrier of IGF-I in blood. Previous studies $[16,26]$ have indicated that the levels of IGFBP-3 are increased during feeding with TPN but are decreased by IGF-I treatment. Although IGFBPs may either inhibit or enhance the biological effects of IGFs depending on specific experimental conditions [28], further studies are needed to define how changes in IGF-I/IGFBPs influence anabolic processes during TPN feeding.

IGF-I treatment influenced organ weight in the gastrointestinal tract, including stomach, intestine and colon, in both $\mathrm{N}$ and $\mathrm{H}$ rats. The increase in body weight observed in IGF-I(+) $\mathrm{N}$ rats was partly due to the increase of the gastrointestinal tract weight. Under several experimental conditions, IGF-I induces an increase in the weight of the spleen and thymus [28, 29]. However, increases in the weight of the spleen and thymus were not observed until after 3 days of IGF-I administration, probably because of the short duration of the treatment. In contrast, under hypoxic conditions the weight of the thymus tended to decrease, suggesting that hypoxia may exert immunosuppressive effects. Thymus weight loss may be related to an increase in corticosteroids as a consequence of hypoxic stress [30]. Hypoxic exposure also caused an increase in the weight of the lungs. Protein content in the lungs was similar in $\mathrm{N}$ and $\mathrm{H}$ rats. The reason why the lung weight increased in $\mathrm{H}$ rats was unclear, but hypoxic lung oedema or blood redistribution maybe one explanation.

It has been reported that $\mathrm{GH}$ can induce salt and water retention, which would lead to an increase in body weight and lean body mass [31]. In this study IGF-I treatment did not affect the water balance in $\mathrm{N}$ or $\mathrm{H}$ rats, while hypoxia itself induced a negative water balance during early exposure (within $24 \mathrm{~h}$ ), but it was not related to the change in nitrogen balance. The water balance in this study was calculated by subtracting urine volume from the TPN solution volume. It did not include respiratory water loss and evaporative skin water loss, thus this balance was always positive. Acute exposure to hypoxia produces an increase in urine volume and sodium excretion 
partly due to a decrease in plasma aldosterone as a result of the suppression of the renin-angiotensinaldosterone system [32]. An increase in atrial natriuretic peptide during exposure to hypoxia may also be related to an increase in urine volume [33]. That could in part explain the decrease in water balance and body-weight gain on day 1 in $\mathrm{H}$ rats.

Exposure to hypoxia induces an increase in ventilation which may be accompanied by an increase in water loss through respiration, although the increase in ventilation would be $\sim 10-15 \%$ when rats are exposed to hypoxia for 3 days [34]. It is difficult to accurately estimate the volume of water in expired gas, because expired gas is not water-saturated. It has been reported that the amount of water vapour depends upon respiratory and environmental factors other than temperature [35]. If a rat weighing $200 \mathrm{~g}$ ventilates about $80 \mathrm{~mL} \cdot \mathrm{min}^{-1} \cdot 100 \mathrm{~g}^{-1}$ under normoxic conditions, the expired gas would be fully saturated. If this rats body temperature is $38^{\circ} \mathrm{C}$ and the temperature in the chamber is $26^{\circ} \mathrm{C}$, the difference in the amount of water vapour between the expired and inspired gas would be $\sim 23 \mathrm{mg} \cdot \mathrm{L}^{-1}$. In such a case the difference in water loss between $\mathrm{N}$ and $\mathrm{H}$ rats would be $0.5-0.8 \mathrm{~g} \cdot \mathrm{day}^{-1}$. Therefore, the degree of difference in respiratory water loss could be minimal between $\mathrm{N}$ and $\mathrm{H}$ rats.

The combined administration of IGF-I and GH could be expected to exert more potent anabolic effects than the administration of either agent alone. Previous studies have suggested that, although IGF-I provides a more direct means for stimulating protein anabolism because the anabolic effects of $\mathrm{GH}$ are mediated in part by increased IGF-I production, the administration of combined therapy could maintain a more normal carbohydrate metabolism and a more normal serum IGFBPs configuration [16]. Further trials are required to define how this combination therapy influences anabolic processes during exposure to hypoxia.

Calorific restriction and negative energy balance represent important components of the catabolic response to acute respiratory failure. During acute exacerbations of chronic respiratory failure due to COPD, it is often impossible to maintain an adequate calorific intake orally to prevent acceleration of protein wasting and frequently parenteral nutrition is needed.

In conclusion, the results shown here indicate that co-infusion of recombinant human insulin-like growth factor-1 with total parenteral nutrition has a significant net anabolic effect, as demonstrated by a reduction in urine protein excretion and improved weight gain and nitrogen retention, compared with vehicletreated control total parenteral nutrition rats. Further studies are required to determine if a similar therapeutic intervention has clinical applications in case of acute exacerbation of hypoxaemic chronic obstructive pulmonary disease patients.

\section{References}

1. Schols AMWJ, Fredrix EWHM, Soeters PB, Westerterp KP, Wouters EFM. Resting energy expenditure in patients with chronic obstructive pulmonary disease. Am J Clin Nutr 1991; 54: 983987.

2. Schols AMWJ, Buurman WA, Staal-vd Brekel AJ, Dentener MA, Wouters EFM. Evidence for a relation between metabolic derangements and elevated inflammatory mediators in a subset of patients with chronic obstructive pulmonary disease. Thorax 1996; 51: 819824.

3. De Godoy I, Calhoun WJ, Donahoe M, Mancino J, Rogers RM. Elevated TNF- $\alpha$ production by peripheral blood monocytes of weight-losing COPD patients. Am J Respir Crit Care Med 1996; 153: 633637.

4. Schols AMWJ, Slangen J, Volovics L, Wouters EFM. Weight loss is a reversible factor in the prognosis of chronic obstructive pulmonary disease. Am J Respir Crit Care Med 1998; 157: 1791-1797.

5. Baarends EM, Schols AMWJ, Mostert R, Wouters EFM. Peak exercise response in relation to tissue depletion in patients with chronic obstructive pulmonary disease. Eur Respir J 1997; 10: 2807-2813.

6. Engelen MPKJ, Schol AMWJ, Does JD, Deutz NEP, Wouters EFM. Differences in amino acid profile of peripheral skeletal muscle between patients with emphysema and chronic bronchitis (abstract). Am J Respir Crit Care Med 1999; 159: A475.

7. Engelen MPKJ, Deutz NEP, Wouters EFM, Schol AMWJ. Enhanced levels of whole-body protein turnover in patients with chronic obstructive pulmonary disease. Am J Respir Crit Care Med 2000; 162: 14881492.

8. Wilmore DW. Catabolic illness: strategies for enhancing recovery. $N$ Engl J Med 1990; 325: 695-702.

9. Byrne TA, Morrissey TB, Gatzen C, et al. Anabolic therapy with growth hormone accelerates protein gain in surgical patients requiring nutritional rehabilitation. Ann Surg 1993; 218: 400-418.

10. Clemmons DR, Underwood LE. Nutritional regulation of IGF-1 and IGF binding proteins. Annu Rev Nutr 1991; 11: 393-412.

11. Carlsson LMS, Clark RG, Skottner A, Robinson ICAF. Growth hormone and growth in diabetic rats: effects of insulin and insulin-like growth factor-I infusions. J Endocrinol 1989; 122: 661-670.

12. Jacob R, Barrett E, Plewe G, Fagin KD, Sherwin RS. Acute effects of insulin-like growth factor I on glucose and amino acid metabolism in the awake fasted rat. Comparison with insulin. J Clin Invest 1989; 83: $1717-$ 1723.

13. Lasekan JB, Rivera J, Hirvonen MD, Keesey RE, Ney DM. Energy expenditure in rats maintained with intravenous or intragastric infusion of total parenteral nutrition solutions containing medium- or long-chain triglyceride emulsions. J Nutr 1992; 122: 1483-1492.

14. Thompson WA, Coyle SM, Lazarus D, et al. The metabolic effects of a continuous infusion of insulinlike growth factor (IGF-1) in parenterally fed men. Surg Forum 1991; 47: 23-25.

15. Mann LT. Spectrophotometric determination of nitrogen in total micro-Kjeldahl digests. Application of phenol-hypochlorite reaction to microgram amounts of ammonia in total digest of biological materials. Ann Chem 1967; 35: 2179-2182.

16. Clemmons DR. Use of growth hormone and insulinlike growth factor in catabolism that is induced by negative energy balance. Horm Res 1993; 40: 62-67. 
17. Koea JB, Douglas RG, Breier BH, Shaw JHF, Gluckman PD. Synergistic effect of insulin-like growth factor-I administration on the protein-sparing effects of total parenteral nutrition in fasted lambs. Endocrinology 1992; 131: 643-648.

18. Kayser B. Nutrition and high altitude exposure. Int J Sports Ned 1992; 13: S129-S132.

19. Butterfield GE, Gates J, Fleming S, Brooks GA, Sutton JR, Reeves JT. Increased energy intake minimizes weight loss in men at high altitude. $J$ Appl Physiol 1992; 72: 1741-1748.

20. Moldawer LL, Lowry SF. Interactions among proinflammatory cytokines and the classical macroendocrine system in sepsis and inflammation. In: Kinney JM, Tucker HN, eds. Organ Metabolism and Nutrition. Ideas for Future Critical Care. New York, Raven Press, 1994; pp 119-136.

21. Hempel SL, Monick MM, Hunninghake GW. Effect of hypoxia on release of IL-1 and TNF by human alveolar macrophages. Am J Respir Cell Mol Biol 1996; 14: 170-176.

22. Morrison WL, Gibson JNA, Scrimegeour C, Rennie MJ. Muscle wasting in emphysema. Clin Sci 1988; 75 : 415-420.

23. Pison $\mathrm{CM}$, Chauvin $\mathrm{C}$, Perrault $\mathrm{H}$, et al. In vivo hypoxic exposure impairs metabolic adaptations to a 48 hour fast in rats. Eur Respir $J$ 1998; 12: 658665 .

24. Ketelslegers J-M, Maiter D, Maes M, Underwood LE, Thissen J-P. Nutritional regulation of insulin-like growth factor-I. Metabolism 1995; 44: 50-57.

25. Ponting GA, Ward HC, Halliday D, Sim AJW. Protein and energy metabolism with biosynthetic human growth hormone in patients on full intravenous nutritional support. J Parent Ent Nutr 1990; 14: $437-441$.
26. Ney DM, Yang H, Smith SM, Unterman TG. Highcalorie toral parenteral nutrition reduces hepatic insulin-like growth factor-1 mRNA and alters serum levels of insulin-like growth factor-binding protein-1, $-3,-5$, and -6 in the rat. Metabolism 1995; 44: 152-160.

27. Clemmons DR. IGF binding proteins: Regulation of cellular actions. Growth Regul 1992; 2: 80-87.

28. Tomas FM, Knowles SE, Owens PC, et al. Insulin-like growth factor-I (IGF-1) and especially IGF-1 variants are anabolic in dexamethasone-treated rats. Biochem $J$ 1992; 282: 91-97.

29. Lemmey AB, Martin AA, Read LC, Tomas FM, Owens PC, Ballard FJ. IGF-1 and the truncated analogue des-(1-3) IGF-1 enhance growth in rats after gut resection. Am J Physiol 1991; 260: E213-E219.

30. Roosevelt TS, Ruhmann-Wennhold A, Nelson DH. A protective effect of glucocorticoids in hypoxic stress. Am J Physiol 1972; 223: 30-33.

31. Burdet L, Muralt B, Schutz Y, Pichard C, Fitting J-W. Administration of growth hormone to underweight patients with chronic obstructive pulmonary disease. A prospective, randomized, controlled study. $\mathrm{Am} \mathrm{J}$ Respir Crit Care Med 1997; 156: 1800-1806.

32. Honig A. Peripheral arterial chemoreceptors and reflex control of sodium and water homeostasis. $\mathrm{Am}$ J Physiol 1989; 257: R1282-R1302.

33. Westendorp RGJ, Roos AN, Simons M, et al. Effects of hypoxia and atrial natriuretic peptide on aldosterone secretion in healthy subjects. J Appl Physiol 1993; 75: 534-539.

34. Olson EB, Dempsey JA. Rat as a model for human like ventilatory adaptation to chronic hypoxia. J Appl Physiol 1978; 44: 763-769.

35. Ferrus L, Commenges D, Gire J, Varéne P. Respiratory water loss as a function of ventilatory or environmental factors. Respir Physiol 1984; 56: 11-20. 